\title{
Multi-user Automated Pageant Tabulation System
}

\author{
Shoven M. Afable, Janice Dyan G. Quiloña
}

\begin{abstract}
This study covered the design, development and evaluation of the pageant automated tabulation system for the local government unit of Can-avid Eastern Samar, Philippines. It aimed to provide tabulation system that can generate result faster and accurate. It used the developmental method of research where an automated tabulation system was developed based on client's requirements. After the development, the application was subjected for quality evaluation for its usability through a questionnaire that was based on IBM Computer Usability Satisfaction metrics for both Alpha and Beta System Testing. During the evaluation, the researchers considered the responses of 8 identified IT experts for Alpha Testing and 88 direct end-users for Beta Testing whom were purposively selected from known local pageant judges and implementers, from the Local Government Unit staff, and the Sangguniang Kabataan Officials of Can-avid, Eastern Samar. The system evaluation results showed an overall rating of 4.60 and 4.39 for alpha and beta tests respectively, which indicates its highly usable software quality.
\end{abstract}

Keywords: Automated Tabulation System, Pageant Tabulation, System Development, System Quality Evaluation.

\section{INTRODUCTION}

T oday, computers are more capable of processing vast amounts of data faster than ever before. Anything can be done with the aid of computers in terms of numerical and logical manipulations. Innovation of things nowadays had emerged. In terms of business, automation of devices and appliances and other computer controlled systems are the trends, wherein the primary purpose of the technology is to make life more beautiful, minimize the workload of people and to make work easier.

Most businesses and even the government uses modern technologies and automation systems for them to be able to serve clients fast and efficient, even different contest from the national television utilizes accurate tabulation system for easy and faster declaring of winners. The most significant technology used in the country recently was the system used during national election through a vote counting machine where in a few days concerned agency can declare winners.

Revised Manuscript Received on January 21, 2020

* Correspondence Author

Shoven M. Afable*, College of Computer Studies, Eastern Samar State University, Can-avid, Philippines. E-mail: venchafable@gmail.com

Janice Dyan G. Quiloña, College of Computer Studies, Eastern Samar State University, Can-avid, Philippines. E-mail: jdgquilona@essu.edu.ph / idgquilona32@gmail.com

(C) The Authors. Published by Blue Eyes Intelligence Engineering and Sciences Publication (BEIESP). This is an open access article under the CC BY-NC-ND license (http://creativecommons.org/licenses/by-nc-nd/4.0/)
For other parts of the community, tabulation for sports events and other contests were using pen, paper and boards, hence, it is quite difficult to calculate and practically consumed a lot of time before knowing who the winners are. Up to present, there were several automated tabulation system developed in the country and abroad to help event organizers in producing accurate results faster. In 2015, an automated pageant scoring and tabulation system was developed at the University of Northern Philippines for use in the Miss CCIT (College of Communication and Information Technology) Pageant and the University wide Miss UNP Pageant. This system allowed any number of judges to enter their scores for varying rounds throughout the pageant. After each category, the system generates results in PDF form ready for viewing and printing where judges are can sign indicating reliability of the results (Fedena, 2015). This way, pageant results were ensured to be accurate per signed hard copy evidence. In this study, the researchers came up with pageant automated tabulation system to help the community during pageant event. This system was intended to help them calculate, tabulate and generate results of the pageant in a timely and accurate manner. The main objective of the study is to develop a LAN-based automated tabulating system for beauty pageant that can (1) display the criteria to be graded; (2) allow judges to enter scores in the system based on criteria; (3) compute, display and print result for specific event automatically; and (4) consolidate and display judges' scores of specific event for easy monitoring by the admin.

\section{METHODOLOGY}

To facilitate easier and faster scoring among pageant events, the researchers conceptualized of developing a personalize tabulation system for local pageants of LGU Can-avid. The required features of the system were gathered and identified based on requirements stated by the target users. These served as basis for the design and the contents of the application. After which, it was subjected for evaluation by IT experts from the University and staff from the local government unit of Can-avid, Eastern Samar.

\section{A. System Development}

An automated system was predesigned and developed for the use of local pageant tabulation in the province, hence, the use of developmental research design through the Rapid Application Development (RAD) model of system development process. Figure 1 below graphically illustrates the RAD method of system development. RAD method is a linear sequential software development process model that emphasized on development cycle using a component based construction approach.

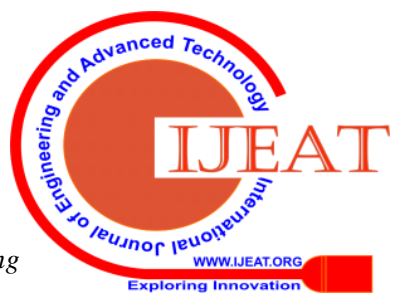


This enables the development team to create a functional application system at a minimal target completion time.The system was developed by Information Technology (IT) professionals of ESSU-C using Visual Basic programming language and MySQL database. The interface was designed appropriately to prospective users, taking into consideration its user-friendliness and easy to use and understand design. This will allow averagely computer literate users to use the application easily and conveniently.

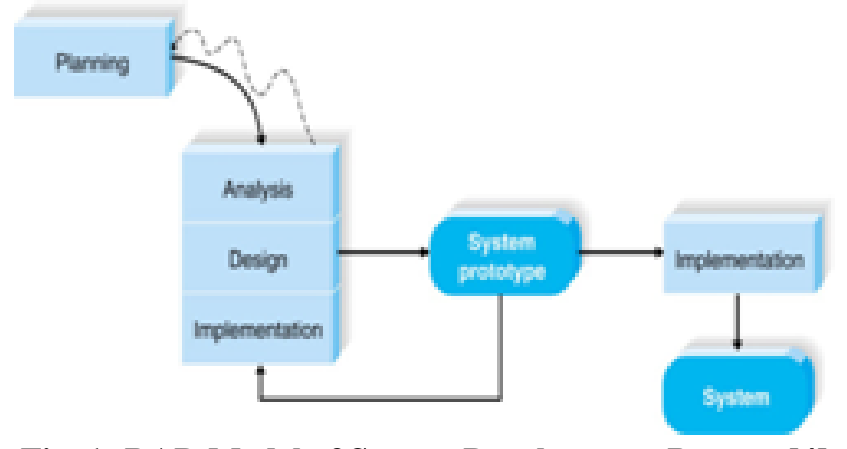

Fig. 1: RAD Model of System Development Process [4]

The researchers establish a possible way to solve the problem including the planning, analyzing, and designing. System requirements were validated by interviewing the intended users for the information needed in making the study. These data was evaluated, processed and was treated as requirements for the study which guide the developers in creating the prototype. Basically, the requirements gathered were transformed into requirements for the prototype and the researchers identified the needed features that would be included in the application.

\section{B. System Evaluation}

After system development, the system was subjected for quality tests on its usability aspects for both alpha and beta testing. Alpha testing is a software evaluation process taken through assessment of the software from the eyes of the IT system experts, while the beta testing gathers the point-of-view of the direct system end-users both to evaluate the system using a system usability questionnaire. In this study, 8 IT experts were asked to do the alpha testing, while 88 respondents were asked to comprised the beta testing group, which includes the selected Local Government Staff of Municipality of Can-avid and Sangguniang Kabataan Chairs and Members from Municipality of Can-avid, Eastern Samar and local pageant experienced judges to comprise the internal evaluators. Table 1 shows the frequency distribution of the respondents.

Table- I: Respondents of the Study

\begin{tabular}{|c|c|}
\hline \multicolumn{1}{|c|}{ Respondents } & Frequency \\
\hline System Experts & 8 \\
\hline Direct End-Users: & \\
\hline$\bullet \quad$ Municipal Tourism Office & 5 \\
\hline$\bullet \quad$ Mayor's Office & 70 \\
\hline $\begin{array}{l}\text { Sangguniang Kabataan (SK) } \\
\text { Officials }\end{array}$ & 8 \\
\hline$\bullet \quad$ Local Pageant Judges & 96 \\
\hline \multicolumn{2}{|c|}{ Total } \\
\hline
\end{tabular}

For both tests, a 15-item system quality evaluation questionnaire was used based on the IBM software usability criteria by Lewis JR in 1995, to measure the usability of the pageant tabulation system. The questionnaire was filled by checking appropriate box per question using the Likert scale with 5 - strongly agree, 4 - agree, 3 - neutral, 2 - disagree, and 1 - strongly disagree.

After evaluation, results were computed using weighted mean (WM). The WM per item and the overall rating were interpreted as 4.20 - 5.0 for Excellent, 3.40 - 4.19 for Very Good, 2.60 - 3.39 for Good, 1.80 - 2.59 for Fair, and 1.0 1.79 for Poor.

\section{RESULTS AND DISCUSSION}

\section{A. System Output}

A pageant tabulation system was developed using Visual Basic. One of the greatest advantages of this software is that its structure is simple, especially the executable code, user friendly and interactive. It has also an integrated development environment (IDE) with easy-to-use tools and utilities that allows for rapid development of software programs.

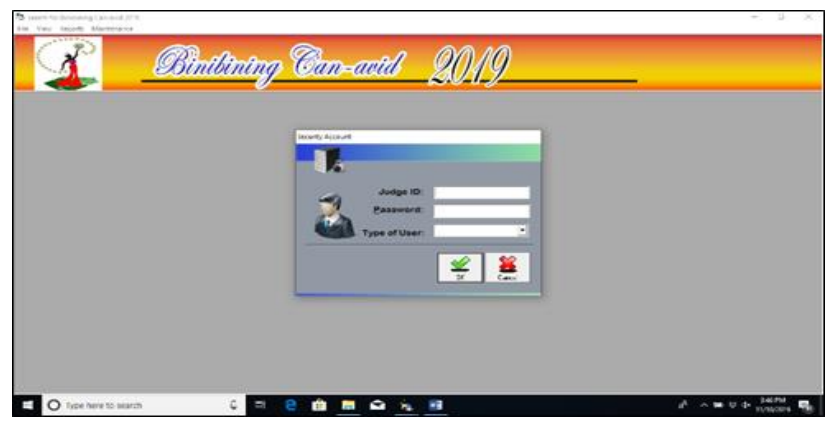

Fig. 2: System Login Form

The system was developed and ensured its efficiency and user-friendliness. The use of the application requires user login for both admin and judges as shown in figure 2 above. The system contains different menus: File, View, Reports, and Maintenance. Under file menu are the sub-menu that includes the different events/exposure of the pageant. View sub-menu are different forms wherein admin can easily monitor scores of the current event/exposure. Report sub-menu includes printing of result. Maintenance sub-menu includes judges' registration and candidates' registration.

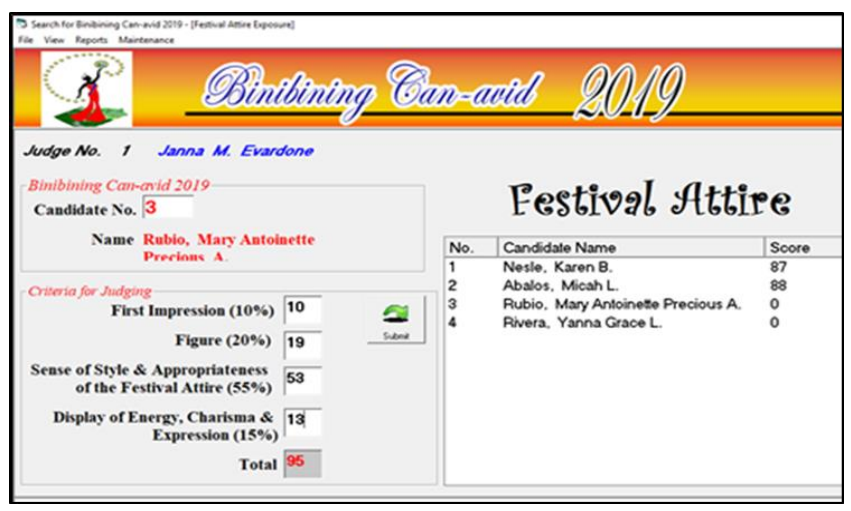

Fig. 3: Pageant Criteria Displayed on Screen for Immediate Scoring from the Judges

Published By:

Blue Eyes Intelligence Engineering

\& Sciences Publication 
Figure 3 shows the form where judge can enter scores of different criteria and store to the database upon clicking the submit button. It also includes data grid view wherein it displays scores given from previous candidates. In this manner, the judge can easily change score by selecting candidate in the data grid view. After all judges were able to submit scores, the admin can easily generate overall rating shown in figure 4.

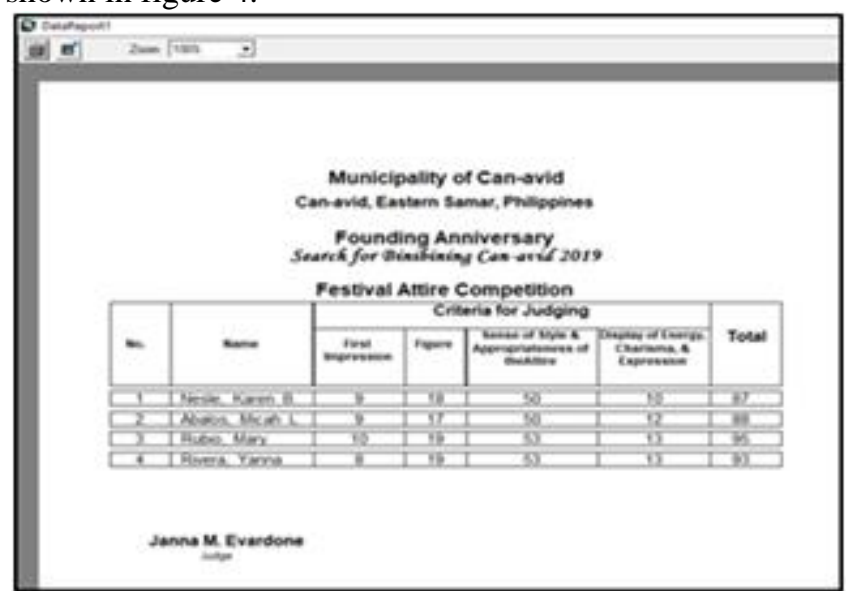

Fig. 4: Preview of Judges Scores

The admin can easily monitor who among the judges are not submitting yet their score, shown in figure 5 . This is the system's way to check users' compliance, as well as ensuring the efficiency and accuracy of the application. After all scores were submitted, results per category and its overall can then be generated by admin in a printable format.

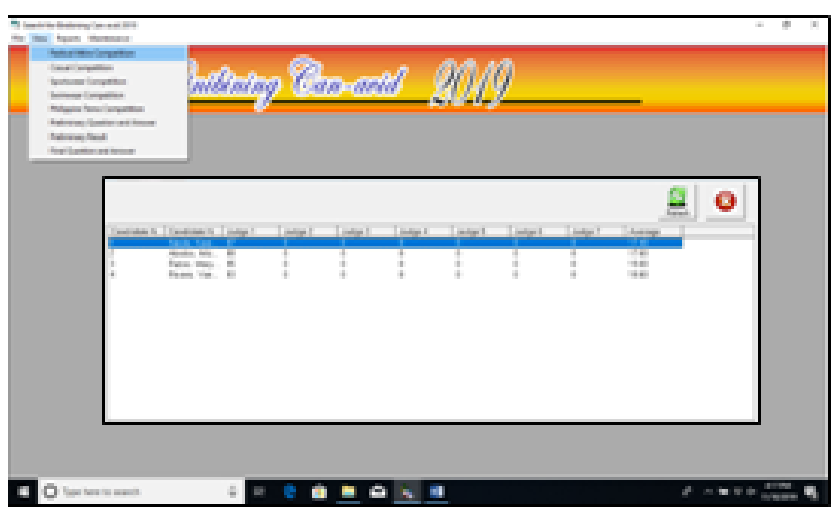

Fig. 5: Admin monitoring view for judges scores

\section{B. System Evaluation Results}

96 system evaluators were asked to evaluate the usability quality of the pageant tabulation system using a questionnaire. These evaluators were composed with 8 IT experts who worked on the alpha test, and 88 client/target end-users who evaluated on the beta test. Both groups utilized the same instrument. After all the respondents have evaluated the system, results were computed using WM and interpreted based on specified interpretation results scheme.

\section{Alpha Test Result}

All 15 items in the usability questionnaire were evaluated by as high usable by the IT experts-respondents in the alpha test, shown in table 2 . Hence, this resulted to an overall score of 4.60 interpreted as highly usable. This results indicates that the IT experts approves for the quality of the application and its usability to the intended users.

Table- II: Alpha Test Results from IT experts-respondents

\begin{tabular}{|c|c|c|c|}
\hline \multicolumn{2}{|r|}{ ITEMS } & \multirow{2}{*}{$\begin{array}{c}\begin{array}{c}\text { Weighted } \\
\text { Mean }\end{array} \\
4.75\end{array}$} & \multirow{2}{*}{$\begin{array}{l}\text { Remarks } \\
\text { Highly } \\
\text { Usable }\end{array}$} \\
\hline 1 & It was simple to use this system & & \\
\hline 2 & $\begin{array}{l}\text { I can effectively complete my } \\
\text { work using this system. }\end{array}$ & 4.38 & $\begin{array}{l}\text { Highly } \\
\text { Usable }\end{array}$ \\
\hline 3 & $\begin{array}{l}\text { I am able to complete my work } \\
\text { quickly using this system. }\end{array}$ & 4.75 & $\begin{array}{l}\text { Highly } \\
\text { Usable }\end{array}$ \\
\hline 4 & $\begin{array}{l}\text { I feel comfortable using this } \\
\text { system. }\end{array}$ & 5.00 & $\begin{array}{l}\text { Highly } \\
\text { Usable }\end{array}$ \\
\hline 5 & $\begin{array}{l}\text { It was easy to learn to use this } \\
\text { system. }\end{array}$ & 4.88 & $\begin{array}{l}\text { Highly } \\
\text { Usable }\end{array}$ \\
\hline 6 & $\begin{array}{l}\text { Whenever, I make a mistake } \\
\text { using the system, I recover } \\
\text { easily and quickly. }\end{array}$ & 4.38 & $\begin{array}{l}\text { Highly } \\
\text { Usable }\end{array}$ \\
\hline 7 & $\begin{array}{l}\text { The information provided with } \\
\text { this system is clear. }\end{array}$ & 4.50 & $\begin{array}{l}\text { Highly } \\
\text { Usable }\end{array}$ \\
\hline 8 & $\begin{array}{l}\text { It is easy to find the information } \\
\text { I needed. }\end{array}$ & 4.63 & $\begin{array}{l}\text { Highly } \\
\text { Usable }\end{array}$ \\
\hline 9 & $\begin{array}{l}\text { The information provided for } \\
\text { the system is easy to } \\
\text { understand. }\end{array}$ & 4.50 & $\begin{array}{l}\text { Highly } \\
\text { Usable }\end{array}$ \\
\hline 10 & $\begin{array}{l}\text { The information is effective in } \\
\text { helping me complete the tasks } \\
\text { and scenarios. }\end{array}$ & 4.50 & $\begin{array}{l}\text { Highly } \\
\text { Usable }\end{array}$ \\
\hline 11 & $\begin{array}{l}\text { The organization of } \\
\text { information on the system } \\
\text { screens is clear. }\end{array}$ & 4.38 & $\begin{array}{l}\text { Highly } \\
\text { Usable }\end{array}$ \\
\hline 12 & $\begin{array}{l}\text { The interface of this system is } \\
\text { pleasant. }\end{array}$ & 4.50 & Usable \\
\hline 13 & $\begin{array}{l}\text { I like using the interface of this } \\
\text { system. }\end{array}$ & 4.63 & $\begin{array}{l}\text { Highly } \\
\text { Usable }\end{array}$ \\
\hline 14 & $\begin{array}{l}\text { The system has all the functions } \\
\text { and capabilities I expect it to } \\
\text { have. }\end{array}$ & 4.63 & $\begin{array}{l}\text { Highly } \\
\text { Usable }\end{array}$ \\
\hline 15 & $\begin{array}{l}\text { Overall, I am satisfied with the } \\
\text { system. }\end{array}$ & 4.63 & $\begin{array}{l}\text { Highly } \\
\text { Usable }\end{array}$ \\
\hline & Overall rating & 4.60 & $\begin{array}{l}\text { Highly } \\
\text { Usable }\end{array}$ \\
\hline
\end{tabular}

\section{Beta Test Result}

The beta test result shown in table 3 below, summarizes the rating from the 88 end-user/respondents. $14 / 15$ of the items were rated highly usable, hence reaped an overall rating of 4.39 interpreted as highly usable. This entails that the end-user agreed to the overall quality of the application.

Table- III: Beta Test Results from End user-respondents

\begin{tabular}{|l|l|c|c|}
\hline \multicolumn{2}{|c|}{ ITEMS } & $\begin{array}{c}\text { Weighted } \\
\text { Mean }\end{array}$ & Remarks \\
\hline 1 & It was simple to use this system & 4.36 & $\begin{array}{c}\text { Highly } \\
\text { Usable }\end{array}$ \\
\hline 2 & $\begin{array}{l}\text { I can effectively complete my work } \\
\text { using this system. }\end{array}$ & 4.28 & $\begin{array}{l}\text { Highly } \\
\text { Usable }\end{array}$ \\
\hline 3 & $\begin{array}{l}\text { I am able to complete my work } \\
\text { quickly using this system. }\end{array}$ & 4.58 & $\begin{array}{l}\text { Highly } \\
\text { Usable }\end{array}$ \\
\hline
\end{tabular}

Published By:

Blue Eyes Intelligence Engineering 
Multi-user Automated Pageant Tabulation System

\begin{tabular}{|l|l|c|c|}
\hline 4 & I feel comfortable using this system. & 4.47 & $\begin{array}{c}\text { Highly } \\
\text { Usable }\end{array}$ \\
\hline 5 & It was easy to learn to use this system. & 4.41 & $\begin{array}{l}\text { Highly } \\
\text { Usable }\end{array}$ \\
\hline 6 & $\begin{array}{l}\text { Whenever, I make a mistake using } \\
\text { the system, I recover easily and } \\
\text { quickly. }\end{array}$ & 4.28 & $\begin{array}{l}\text { Highly } \\
\text { Usable }\end{array}$ \\
\hline 7 & $\begin{array}{l}\text { The information provided with this } \\
\text { system is clear. }\end{array}$ & 4.44 & $\begin{array}{l}\text { Highly } \\
\text { Usable }\end{array}$ \\
\hline 8 & $\begin{array}{l}\text { It is easy to find the information I } \\
\text { needed. }\end{array}$ & 4.50 & $\begin{array}{l}\text { Highly } \\
\text { Usable }\end{array}$ \\
\hline 9 & $\begin{array}{l}\text { The information provided for the } \\
\text { system is easy to understand. }\end{array}$ & 4.41 & $\begin{array}{l}\text { Highly } \\
\text { Usable }\end{array}$ \\
\hline 10 & $\begin{array}{l}\text { The information is effective in } \\
\text { helping me complete the tasks and } \\
\text { scenarios. }\end{array}$ & 4.28 & $\begin{array}{l}\text { Highly } \\
\text { Usable }\end{array}$ \\
\hline 11 & $\begin{array}{l}\text { The organization of information on } \\
\text { the system screens is clear. }\end{array}$ & 4.31 & $\begin{array}{l}\text { Highly } \\
\text { Usable }\end{array}$ \\
\hline 12 & $\begin{array}{l}\text { The interface of this system is } \\
\text { pleasant. }\end{array}$ & 4.06 & Usable \\
\hline 13 & $\begin{array}{l}\text { Ilike using the interface of this } \\
\text { system. }\end{array}$ & 4.58 & $\begin{array}{l}\text { Highly } \\
\text { Usable }\end{array}$ \\
\hline 14 & $\begin{array}{l}\text { The system has all the functions and } \\
\text { capabilities I expect it to have. }\end{array}$ & 4.44 & $\begin{array}{l}\text { Highly } \\
\text { Usable }\end{array}$ \\
\hline 15 & $\begin{array}{l}\text { Overall, I am satisfied with the } \\
\text { system. }\end{array}$ & 4.47 & $\begin{array}{l}\text { Highly } \\
\text { Usable }\end{array}$ \\
\hline & $\begin{array}{l}\text { Highly } \\
\text { Usable }\end{array}$ \\
\hline
\end{tabular}

\section{AUTHORS PROFILE}

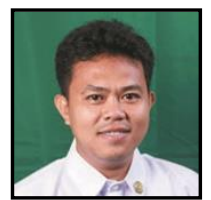

Shoven M. Afable, is a faculty of Eastern Samar State University Can-avid Campus, Philippines with Master's Degree in Teaching Vocational Education major in Information and Communication Technology. At present, he is designated as Program Head of the university's BS Information Technology program. Concurrently, he works as Planning Officer as well as the Head of the IT Solutions Division of the Campus

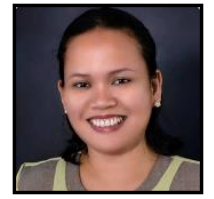

Janice Dyan Grata-Quiloña, is a faculty of Eastern Samar State University Can-avid Campus, Philippines. She graduated her Master's Degree in Information Technology at ADFC Tacloban City, and completed her academic requirements in Master of Science in Computer Science at the University of the Philippines Los Baños Laguna. Currently, she is on her $3^{\text {rd }}$ year of Doctor in Information Technology Program at Cebu Institute of Technology - University, Cebu City Philippines. She has completed several research studies that focused on IT, education, and the environment, where she won best research paper including her research project on a Decision Support System for Mangroves Restoration in Eastern Samar, and Employers Perception on the Graduates of Eastern Samar State University.

\section{CONCLUSION}

The pageant tabulation system was developed by IT experts of ESSU-C. The development was based on the requirements of the application as perceived by the end-users. The programmers ensured it simplicity, accuracy, and usability. Hence, display of the required criteria were ensured. Tabulation and computation of the scores for each category of the event were provided to be accurate, faster, and with reliable result, up to its printable format. Overall, the pageant automated tabulation system met the requirements identified by the client considering an overall excellent evaluation results for both alpha and beta tests on its usability quality.

The developers highly recommends implementation of the pageant automated tabulation system in the community during pageant event for accurate, fast, easy to use and efficient tabulation system.

\section{REFERENCES}

1. D. Wallach, et. al. (August 18, 2008) Analysis on Electronic Voting System. [Online].

Available: http://avirubin.com/vote/analysis/index.html

2. A. Azguire. (2008, August 18) Advancement of Tabulation System, [Online]. Available: http://www.cdc.gov/nchs/sets.htm

3. A. Gill. (2006).International Patent Organization. Automated Voter Registration and Tabulation System. [Online]. Available: http://www.wipo.int/pctdb/en/wo.jsp?

4. Automated Beauty Pageant Scoring and Tabulation System, [Online]. Available: http://www.findbestopensource.com/product/agjudgetayon

5. [Online].

Available: https://www.inettutor.com/source-code/tabulation-system-in-php-mysq l-and-bootstrap-capstone-project/

6. Anonymous. What is Automated Tabulation System? [Online]. Available: http://www.goelite.com /modules/contents/

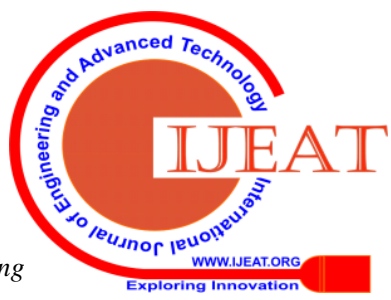

